\title{
Eastbound - Westbound: Re-reading the Myth of Europa
}

\author{
Bert van Roermund* \\ Tilburg University \\ The Hetherlands
}

Received 12.11.2015, received in revised form 17.12.2015, accepted 05.01.2016

Europe's identity is not just contested. It is contested in specific terms, namely which set of properties (values, heritage, or vocation) would uniquely identify Europe? Major ramifications allegedly follow from whatever stance taken in this debate, e.g. with regard to external relations (should the Union come to include Turkey?) and internal institutionalisation (is there a European demos?). Without exception, these arguments derive from representations of Europe's past. This paper challenges this common bias, taking a cue from Merleau-Ponty's distinction between 'Europe en représentation' and 'Europe en acte'. It does so by tracking, firstly, how the narrative of Europe's past vanishes into a myth that we cannot represent but also cannot cut loose from. Secondly, it revisits the incisive critique of a representationalist view on Europe which Nietzsche confronted us with. Here I first address Nietzsche's explicit, but scattered, notes; then I explore how the same themes are played out in what I consider to be one of the greatest novels on 'Europe' of the 20th century, Musil's The Man without Qualities). Thirdly, the paper argues that the alternative reading of identity in terms of 'Europe en acte' allows us to deploy the myth of Europa in prospect rather than retrospect, to bear in mind the multiple ways in which various polities within European lost their innocence, and to stand united in an attitude of prudence with regard to at least three major praxeis of the future: technology, economics and the rule of law. Hence, shared selfhood rather than shared sameness should inspire the terms of the identity debate.

Keywords: European identity, selfhood and sameness, East-West relationship, political boundaries, Nietzsche.

Article is devoted to the Law Institute jubilee.

DOI: 10.17516/1997-1370-2016-9-1-235-250.

Research area: law.

In memory of Willem Witteveen law and humanities.

\section{By way of a preface}

There are many reasons to congratulate the Law School of the Siberian Federal University on its 60th anniversary. One of these is its openness towards the idea of law as a transnational rather than a national concern. Another is its interest in academic disciplines adjacent to law such as social sciences and humanities. That these two qualities form the helices of the Law School's DNA becomes particularly (though not exclusively) visible in

(C) Siberian Federal University. All rights reserved

* Corresponding author E-mail address: G.C.G.J.vanRoermund@uvt.nl 
the Comparative Law Department of the School, where I have always found a curious, critical, and hospitable environment of students and faculty. For that I would like to add my gratitude to my congratulations.

This special issue celebrates the anniversary of the Law School by exploring some links between law and humanities, and by refuelling close relationships between colleagues from East and West in this area, that have come to flourish over recent decades. The much appreciated invitation to contribute a paper came to me on the ominous $14^{\text {th }}$ of July, 2014, the day of the MH17 crash over East-Ukraine, in which 298 innocent people died. Among them were my near colleague Willem Witteveen, his wife Lidwien Heerkens and their daughter Marit. An expert in legal theory, in particular law and literature, and founding father of the Liberal Arts Programme at Tilburg University, Witteveen was 'law and humanities' in the flesh. An academic and a senator, he was also an ardent defender of the rule of law as a global concern. Therefore, I take liberty to dedicate this essay to his memory, knowing that he would have encouraged me, as well as our East-going colleagues over the years ${ }^{1}$, to maintain the academic links with SFU, in spite of the growing concerns emerging, as we speak, in our Western countries about some major policy decisions of the Russian Federation, both internal and external. We in the West wonder, indeed, how, for instance, the Federation would defend the occupation of Crimea in view of its responsibility as a permanent member of the United Nations Security Council; or how it would compare the investigations procedures to identify, respectively, who brought down MH17, and who attacked Airbus A321 over Egypt's Sinai desert in October 2015, killing 224 people; or how it would see the core of democracy in relation to freedom of speech for those who severely criticise the parties and powers in office. Witteveen would trust that these concerns would be no secret to our Russian colleagues and students, and he would have challenged us to discuss them in all openness. But he would also acknowledge that such discussions require an attitude of mutual confidence and honesty between East and West.

In this paper $^{2} \mathrm{I}$ hope to be responsive to Willem Witteveen's appeal, in a self-critical vein, by scrutinising the ways in which we in the West ask about Europe's identity. I propose to ask the question about the identity of a continent that lacks a border to the East, where it vanishes into Russia; only no one knows where. Indeed, I am going to revisit, from a philosophical point of view, the common phrase of Europe as an appendix, or a large peninsula, of Asia. ${ }^{3}$ Only from such an investigation, I venture, will we be able to discover what we are talking about when we express concerns regarding, e.g., 'European' (or, for that matter, 'Asian') values, democracy 'deficits', 'transboundary' legal developments, etc..

\section{Ereb and arab}

Could it be true? A rather simple etymology ${ }^{4}$ would allegedly derive the name 'Europa' from an old root that consists of a pair of consonants ( $\mathrm{rp}$ or $\mathrm{rb}$ ). These would have been vocalised in two different ways. One would use a high vowel $e$, the other one a deep vowel $a$. This vocalisation would have made these sounds apt for indicating contrasting pairs. Similar to our saying 'pingpong', 'cat and dog', or 'tit for tat', people in the old times would have used erp and arb or, slightly stretched, erep and $a r a b$. It could have been indexicals to point to regions, generously, with a wide arm gesture: yonder and yonder. And what else would have constituted the difference between these two horizons than the most pertinent difference to be made on earth wherever one has chosen to dwell: the land where the sun 
sets and the land where the sun rises? Too good, perhaps, to be true.

However, if we embark on a description of European culture with these etymological surmises in the background, a disturbing order of things begins to take form. The issue of solemn names, for instance: Europe as the Occident, the 'Night Land', the 'First World'. It is quite obvious that erep-land could only have been the Night Land and arab-land the Morning Land. For that part of the globe - America - where Europe would become the oriental Morning Land and Arabia the occidental Night Land was yet unknown to the word wizards of these ancient times. It is equally obvious that Europe was bound to become 'the First World'. For it is a wellcorroborated phonological law that high-pitch vocalisation precedes low-pitch, presumably to burden our acoustic senses by alerting them one step at the time. We easier hear, and therefore say, 'ereb and arab' than 'arab and ereb', for the same reason as we prefer to say 'ping-pong' rather than 'pong-ping'. The high-pitch vocalisation is more suitable to awaken our ears and attract focussed attention to what follows, where the low-pitch one would make the light vowels disappear in its acoustic shadow.

Interesting as it may be in its own right, the matter of names is not the most important one. More fascinating is the following observation. If we try to frame a retrospect of our cultural history we are able to point, with great certainty, to the place where these words ereb and $a r a b$ must have made their first sense. Seen from the present situation there can have been only one area in the Ancient World, where ereb could stand for what is now, roughly, Europe and $a r a b$ for what in our days is the Arabian World. There can have been only one topos from where we point to Europe if we refer to the land where the sun sets and to Arabia if we turn to the land of the sunrise. This topos is to be found at the easterly coast of the Mediterranean Sea, the old Phoenician shores.

By a felicitous coincidence, mythology comes to underscore etymology on this point. Most of us will be familiar ${ }^{5}$ with the old Greek narratives telling that Europa was the name of the pretty daughter of a Phoenician king. Zeus kidnapped her when she was playing with her friends in the fields near that east shore. He appeared before her in the guise of a white bull. Playful as she was, she gradually turned from her friends to this magnificent animal ${ }^{6}$, began to decorate his head with flowers and eventually mounted his white back. The bull started running towards the sea. He splashed into the water with his rider. Together they drifted westbound. They must have looked right into the setting sun. Why? Well, otherwise the girls would not have been playing there! In these regions evening is the time to find a bit of cool air at the beach, to rest and to play. ${ }^{7}$ When they arrived at the isle of Crete, bulls' island indeed, and as west of the Phoenician shore as can be, the tables are turned. Now it is Zeus's turn to mount a white back. He rapes the young woman near a source, symbol of fertility, and leaves her behind in distress. The myth concludes with Aphrodite coming to comfort Europa and to promise her that once a whole continent will bear her name.

Such is, in rough outline, the narrative in which the history of Europe vanishes. It is, perhaps, an all too emphatic support of the hazardous etymology that we applied on the few letters of that name. We may feel uneasy about the love of ostentation that is so quick to make etymology and mythology conflate. Would we not rather spend our wit to the real problems Europe has to face? But if we would turn our head from so intellectual a posture, and if we would try to focus on the real issues in contemporary Europe, we would still be looking at the eastern coast of the Mediterranean. We would ascertain, 
with a heavy heart, that it is there, near these very shores of the Mediterranean, where Europe's identity is still a cause of serious battle, often in the literal sense of the word. It is hardly necessary to mention examples. In ever so many discussions about the broadening of the European Union, political protagonists find themselves in opposite camps regarding the possible candidature of Turkey. Although Turkish soccer clubs are welcome to join the European Champions League, our politicians are very reluctant to let Turkey participate in the project of a united Europe. The sternest argument heard is not the economy, nor is it the doubtful situation of human rights and democracy in Turkey. It is, rather, the observation that Turkey is the representative, indeed the frontier soldier, of a different culture. Cynical as it may sound, Turkey's poor performance in human rights and democracy is a welcome excuse, for the time being, to silence this much more categorical statement on culture. It will almost certainly be revisited as soon as human rights and parliamentary democracy in Turkey appear to improve. Turkey marks the culture that 'we', Europeans, have repelled from the shores of Phoenicia during the great crusades. It is the culture that we have resisted when it threatened the gates of Vienna. It is the culture that cuts across Cyprus. It is the culture that turned the Balkan into a powder-barrel of violence. It caused the hills around Blace in northern Macedonia to mirror those of Goma in eastern Congo. In short, it is the $a r a b$-culture that the ereb-culture has to oppose for the simple reason that the two have always been face to face. ${ }^{8}$

The same clash is brought on our retinas almost daily by yet another conflict on the Phoenician shore, where the far posts of the ereband the $a r a b$-culture contest each other's claim on the land that the one calls Palestine and the other Israel. If one travels around in this region, if one manages to escape from the state authorised tourist places and to go one's own way, it is not difficult to assess that here, on the Phoenician shore, people live on a political St Andrew's crack. From the relatively safe corner of the western European world we can wonder how vehement the battle is over every acre of ground that could be occupied by one or the other of the two cultures clashing here. ${ }^{9}$ And, like in the case of the Balkan, Europe feels unable to interfere. Not so much because it is extremely difficult to establish who is in his right and who is not, but rather because we see ourselves reflected in this battle and realise that our ancient anti-Semitism was only moved to a different place. ${ }^{10}$ Should we not be prepared to admit that Europe was happy to let the survivors of the Shoah go to the frontier line of its culture: back to where they came from? If such questions emerge, it is perhaps time to acknowledge that there is more at issue than a scholastic exercise in etymology and mythology.

\section{Nietzsche and Europe}

Could we only learn to say ereb again if we meant Europe: yonder. Could we just point 'yonder' in those sublime discourses on identity! Sublime and manifold as they may be these days, they are myopic to the point of narcism, rather than a longing gaze at the horizon. The urge to put the issue of identity on the agenda seems to have increased since 'the fall of the wall' (1989), the year when Europe became again what, in point of fact, it had always been: a continent that is little more than an appendix of Asia - as Nietzsche used to asser ${ }^{11}$; a continent that misses one border and, thus, does not know where it ends. In our day it would seem that the quest for Europe's cultural identity is a prerequisite of any political enterprise claiming accountability. Thus, from the part of the advocates of transparent European developments it often is the object of sincere concern. I refer, for example, to the carrefours, the round table conferences initiated by the former chairman of 
the European Commission, Jacques Delors. 'As the European institutions', he asks,

'no longer express by themselves a dynamics palpable to the citizens, as the political mediations of our different countries are no longer designed to justify a long term project, is it not the task of philosophers, historians, political scientists and, indeed, also the representatives of the sciences, to indicate a direction for contemporary Europe? $?^{12}$

No one will dispute the relevance, or indeed the need, of an intense project of constant reflection by such a fine selection of distinguished scholars. But the very same quest for identity is also undertaken in order to stop the growth of transparency in European institutions. Then it serves the argument that where there is no European nation with its own identity, there can be, ultimately, no democratic credentials for European law, unless it is accepted by the national legislators of the Member States. I refer to the decisions of the Bundesverfassungsgericht on the Lisbon Treaty of the European Union. ${ }^{13}$ Not that I want to take issue with all the various lines of argument that compose this Lisbon-Judgment, some of which make perfect sense with regard to the well-known problem of the democratic deficit in the Union. But to understand what is in the background of this ruling one may want to read the lawyers responsible for its conceptual framework, like Paul Kirchhof and (even more revealing) Karl Albrecht Schachtschneider: in the name of democracy they persistently raise the topic of 'natural homogeneity' of the people as a necessary terminus a quo for a political order under the rule of law. The latter, towards the end of a thousand two hundred pages sustained exercise in legal philosophy, is not embarrassed at all to emphasise the 'biological homogeneity' of the
Europeans and to express his high expectations that this, eventually, will form the basis of their transnational unity. ${ }^{14}$ One thing I learnt from my travels to Middle Siberia is that this is utter nonsense. Indeed, there are more subtle ways of regenerating racism.

The revival of this political issue of identity during the last two decades is all the more remarkable as it seemed to have been ruled out shortly after the Second World War by the initiatives of economic co-operation. The odds were that the warrant of peace could not be found any longer in letting 'the spirit of Europe' range once more over the nations. Rather, a better world was expected to come from the technological organisation of a market for basic economic processes, common for member states only. This was not devised as a crude form of mercantilism. Well on the contrary, the market should be seen as a public good in itself; a good that could only exist if certain ways of acquiring or maintaining property, together with incentives of open competition, would be enforced by an overarching structure of legal power. Such power would be regarded, in one way or another, as sovereign. But, quite different from national state sovereignty, this power would hide, as it were, behind the ongoing processes of the market itself, where all the participants would be free to negotiate on an equal basis. Nevertheless, governmental power should be real and effective, to be exercised by Commission, Council and Court, as well as, though to a far lesser degree, by some form of parliamentarism. Thus, the whole project was marked off from an all too stylish Renaissance of 'la douce commerce'. Am I saying, by pointing to the renewed growing appeal to an idea of European identity, that, at this point in time, we begin to realise that this project of piecemeal engineering has fallen victim to its own success in practice, or its fallacy in theory? and that the issue of identity has to come to its rescue after all? 
It seems so, certainly in view of the risky Eurozone project; the upheaval caused by the influx of large numbers of undocumented immigrants; and the rapidly deteriorating relationship with the Russian Federation. It looks as if there is no point in having a single market without a single currency, and no single currency without a single ultimate source of political power; and no single source of power without a polity regarded itself as a bounded whole. But I also hesitate if this explanation suffices.

In the '90ties Francis Fukuyama made a best-seller with the old idea that this type of lucid liberalism constituted 'the end of history'. ${ }^{15} \mathrm{He}$ did not mean that the course of events in the world would come to an end. His thesis was, rather, that, from our time on, the meaning of events, whatever their nature, can be justifiably assessed from only one convincing perspective: whether they contribute to or carry away from what the market requires. Had he read Nietzsche, he would probably have approached the matter with more caution. ${ }^{16}$ Nietzsche pre-sensed that nothing would be able to stop the economical unification of Europe - and he abhorred it. Here are a few of his last and most visionary phrases ${ }^{17}$ :

Die wirthschaftliche Einigung Europas kommt mit Nothwendigkeit - und ebenso, als Reaktion, die Friedenspartei ...

Das Ringen um einen Vorrang innerhalb eines Zustandes, der nichts taugt: diese Cultur der Großstädte, der Zeitungen, des Fiebers und der 'Zwecklosigkeit'.

11[236]

Eine Partei des Friedens, ohne Sentimentalität, welche sich und ihren Kindern verbietet, Krieg zu führen; verbietet, sich der Gerichte zu bedienen; welche den Kampf, den Widerspruch, die Verfolgung gegen sich heraufbeschwört; eine Partei der Unterdrückten, wenigstens für eine Zeit; alsbald die große Partei. Gegnerisch gegen die Rach- und Nachgefühle.

Eine Kriegspartei, mit der gleichen Grundsätzlichkeit und Strenge gegen sich, in umgekehrter Richtung vorgehend -

This passage is one that is full of cynicism. Contrary to what one might think, Nietzsche is not warning against a belligerent party. What he worries about, rather, is a pacifist party established by economic forces. He warns against forces that had probably made themselves felt already in 1888, and that would take full effect in the course of the following century, ending exactly a hundred years later in 1989. In any event, he opposes the moral unison that, inevitably, will come in the tail of economic unification. Instead, he advocates a war party with the same cogent logic and discipline marching in the opposite direction: a party that does not make unity for its own sake sacrosanct and, thus, a party that steers away from Christian morality.

For Nietzsche, European Christian 'morality' is deeply perverse. As is well-known, it annoys him already in Die fröhliche Wissenschaft. ${ }^{18}$ It is a morality that wants to ban all contingency, all tentativeness, all conflict, in short: all heterogeneity. ${ }^{19}$ We Europeans, he says, are tired of difference. We, the good Europeans of today and tomorrow, are tired of man. This fatigue is the nihilism that Nietzsche wants to fight, although he has little hope of success. For that is precisely what is blurred: the memory of every form of difference, singularity and plurality:

$$
\begin{aligned}
& \text { 'A poet could say that God has put Oblivion } \\
& \text { as a guard at the doorstep of human } \\
& \text { dignity. }{ }^{20}
\end{aligned}
$$

The European man, according to Nietzsche, has lost the awareness of what he has destroyed, 
robbed and murdered in the name of human dignity. Now he empowers himself to reconstruct his history as moral progress, and the slightest sign of hesitation, let alone protest, as a contempt of his excellence. Once again:

\begin{abstract}
'Wer das Gewissen des heutigen Europäers prüft, wird aus tausend moralischen Falten und Verstecken immer den gleichen Imperativ herauszuziehen haben, den Imperativ der Heerden-Furchtsamkeit: 'wir wollen, dass es irgendwann einmal nichts mehr zu fürchten gibt!' Irgendwann einmal - der Wille und Weg dorthin heisst heute in Europa überall der 'Fortschritt'. ${ }^{21}$
\end{abstract}

The pagans of progress, the insolent ones, should be taught manners, indeed mores; that is what christian morality is after. To which end, they think, this morality, this clear cut distinction between good and bad, should be presented as a universal and eternal certainty ${ }^{22}$ that justifies both supreme violence and extreme cowardice. Who shall have the courage to resist it? And Nietzsche challenges us, Europeans: those who shall have the courage to depart from this morality, this self-appropriated self-confidence, and to reach beyond this premature distinction between good and bad, those shall become, in Nietzsche's much abused idiom, Übermenschen.

Thus, Nietzsche abhorred the economic unification of Europe. But he abhorred it for a reason quite different from the worries vexing the authors of our times. They picture us, Europeans, as if we are on the verge of losing our culture by yielding to the pressure of economic developments. He, Nietzsche, believed this unification to be an inevitable outcome of a perversity in European culture. Thus, it is not something that European culture could be called to arms against, or even fall victim to. Those who oppose European culture and European economy (that is, the hard facts of uniformity, indifference, pollution and finally destruction), resemble the biblical character who wants to exorcise the devil by Beelzebub. For it is this very culture, this spirit of Europe or Europe as an idea, which is as Nietzsche sees it - the root cause of economic unification. This spirit, eventually, will whiten all differences by erasing everything that is really different, from cheese to music, from agriculture to fine arts. The spirit of Europe takes issue, in particular, with everything that could be suspected to undermine the established distinction between good and bad. Even one who is not inclined to grant him prophetic talents will conceed that this Nietzschean account of our moral certainty might well provide the only explanation of our imperturbability under the nuclear, the ecological and the capitalist threats. Europe is the birthplace of the belief that it is good to exterminate man in the name of man, if necessary multiple times.

It is not easy to truly face Nietzsche's challenge. Our first reaction is to squarely contradict him. We feel the urge to reassure each other that he was this biased pessimist who only would see the bad side of things; that, indeed, Europe has its good sides along with the bad ones, and that we can always learn from the mistakes of the past. In particular we want to stress that Europe derives its identity from the diversity of cultures and that opening up to that diversity will offer it precious chances for the future. These encouragements may keep the spirits high in everyday life. In point of fact, however, they are perfect demonstrations of what Nietzsche meant: the bourgeois belief in moral progress that appeals to 'the jewish-christian tradition' and 'the Greek logos' - or if one prefers the secular variant: the appeal to human rights and democracy.

It is therefore necessary to be more precise about what it was that Nietzsche attacked. And because our spontaneous reaction will almost certainly be biased by our need of self- 
legitimation, we may welcome a more vivid picture of these biases, so as to recognise them quicker. Let us try and achieve this by turning to the literary character of Arnheim in Musil's unfinished novel The Man Without Properties.

\section{Arnheim as a European}

One of the narrative lines in the first part of Musil's novel concerns the fuzz about the socalled Parallel Action. Ulrich, the main character of the novel, is 'the man without properties', i.e., he is not really committed to anything. He gets involved in this Action as a special secretary to a committee, consisting of half nobility, half bourgeoisie, that has charged itself with a grand plan. It is determined to outbid the upcoming Prussian celebration of Wilhelm II's thirtieth anniversary as a king by a simultaneous (thus parallel) one year celebration of the seventieth anniversary of Kaiser Franz Joseph in the double monarchy of Austria and Hungary. Both the godfather and the godmother of this action engage in the most bragging of rhetorics to persuade all their social circles that there is need for one unifying idea that will found the whole of the action and be an epitome for the world at large. Soon enough, however, when it comes to grand ideas they have to hand over to a big captain of industry who, at the same time, is a philosopher in his own right. It is dr. Paul Arnheim, and he is a Prussian.

Arnheim is characterised ${ }^{23}$ as an enormously wealthy and powerful person, who nevertheless asserts to be permanently in search of the spiritual value of material life: 'the unification of soul and economy' (140). His overall goal is 'to take ideas into spheres of power'. His Prussian origin is regarded as only a minor stain on his record. $\mathrm{He}$ is believed to be someone who is able to transcend nationalist scantiness. Yes, he is truly a European (226; 261). Thus, he incorporates a philosophy in which everything can be accommodated and ascribed a place. (231). He is someone who knows to speak of 'the mystery of wholeness' (251), someone also who is a great admirer of that other world-embracing provider of wholeness, the Catholic Church (242). In short, he is, totally committed, the antagonist of Ulrich. The latter is terribly annoyed by all these pretensions as they converge in one slogan that is of massive persuasive force for every politician, to wit that one must first be able to use power before one will be able to use power to the good.

Arnheim's conception of culture, his Europeanism, converges into oppressing every trace of doubt, of heterogeneity and, above all, of contingency. He does not believe that, all of a sudden, something extraordinary can happen, something never heard of, something that baffles the mind and defies everyone's understanding. For him, it is self-evident that there is an undeniable 'meaning' in life and that this overall meaning nourishes all categories that will serve us to book each and every state of affairs or course of events according to their 'Sinngehalt'. There are assets and there are liabilities, the kind of accountability that is governed by accountancy; and that is all there is. 'European' in particular is his belief in a certain version of the principle of sufficient reason. - 'In world history nothing happens without reason', he says to Ulrich. - 'But it does in the world', Ulrich responds. - 'In world history never!', (225) Arnheim reassures him at their first meeting, apparently referring to the all-embracing Hegel. Ulrich however, Arnheim's antipode, is a great believer in the principle of insufficient reason, which he amply explains to deputy bank director Leo Fischel.

If Arnheim is Nietzsche's European in The Man Without Properties, can we then say that his antagonist, Ulrich, is the literary counterpart of the Übermensch? Many readers would assign that role to Clarisse. She is the fanatic half of a couple for whom Ulrich has some ambivalent and 
rather superficial feelings. But he cannot follow Clarisse in her fascination with Moosbrugger, the murderer of several women, whose imprisonment forms another narrative line in the novel. This fascination, indeed, seems to carry her 'beyond good and evil'; for who else would be on the side of someone who has done all these terrible things? An attentive reader would also notice that Ulrich gives Clarisse Nietzsche's collected works as a present at her wedding. He would perhaps infer from this scene that ' $(. .$.$) she has$ so completely absorbed the Nietzschean message that she has made herself - as far as it is possible to translate a philosophical insight into a mode of living - an embodiment of Nietzsche's "Will to Power". She is obsessed with Nietzsche's idea of the redemption of mankind by the chosen few. ${ }^{24}$ So Clarisse, rather than Ulrich, would be the Nietzschean Übermensch?

It could well be a premature interpretation. Ulrich's gift could be an antidote to Clarisse's doting, to fiddle a fashionable idiom. For who else than the true Nietzschean can give the collected works and say in an angelic voice: 'Tolle, lege' Take and read? Who else than someone who truly understands these works can give them as a personal present? Is this not, indeed, always the implicit message behind every book that we give? And whom else could these works be given to than to someone who has still to learn the core of it, because she is inclined to subject her whole environment to her whimsical fanaticism? Indeed, we will see Clarisse, in the course of the book, consulting the works, rather than reading them. She wants to find instructions in them, as if Nietzsche's text were an oracle ${ }^{25}$ or a recipe book.

No, there is certainly more similarity between Nietzsche's cynicism and Ulrich's resistance against Arnheim. Payne notes in his reflection on Musil: 'Musil may have been thinking of Ulrich when he wrote in one of his manuscript notes:
"Socratic is: to feign ignorance. Modern: to be ignorant!'( $\mathrm{Tb}$ [= Tagebücher, BvR], II, 736'. ${ }^{26}$ And Nietzsche, as we know, hated Socrates as vehemently as he did Christian morality. We may conclude, therefore, that Ulrich comes closest to that man that Nietzsche has in mind when he referred to the man 'hors catégorie', the man beyond man, the Übermensch. The man beyond man is not superman. He is the man that will reach beyond Socrates, beyond the Greek, to the Phoenician shores. He is the man without qualities because he is pure potentiality. But this comes at a price: he is totally powerless. For this he will pay dearly.

\section{Europe 'en acte'}

When we speak of the identity of Europe, we often speak like Arnheim: we want to bring ideas into spheres of power and advocate the convergence of economy and spirit. We reach to the Greeks, but not beyond Socrates. If we read the myth of Europa at all, we read it as a metaphor, a spiritual image that has not stopped 'speaking' to us. But this is only because we find ourselves able to bring out its 'meaning', a meaning that we made sure to carefully store there long in advance. Our strategy is to map this identity on to an origin from which it all emerged. We habitually speak of the cradle of our civilisation and refer to the eastern shores of ancient Judaism, to the somewhat nearer ancient Greece, to the even closer ancient Rome. Then we are in fact home, as the remnants of the Roman Empire can be found quite far west, even in the Dutch Rhine delta or, for that matter, across the North Sea, in England. Indeed, new remnants are discovered on a regular basis, every time when we turn our spade to create socalled new infrastructure.

In this way, we tell the Europa myth in the form of a retrospective on the myth itself. We skip the myth as it were and turn directly to the 
spirit behind the letters or the vocation behind the vowels. We tell ourselves a myth about this myth, as we believe ourselves to be able to reveal its ultimate sense and reference in the future. We imagine to be even beyond Aphrodite, knotting approvingly to her promise because we know how the story ends; namely with 'us'. In retrospect, we emphatically say to ourselves, Europa came to the right place: to us and our idiosyncracies. Let me call this perspective on European identity a 'vocational' one, as it derives from the selfdedication to an image of our own perfection. The whole of history is reconstructed to produce, as it were, this Europe, even though we are quick to admit that there have always been sustained efforts to undermine the road to perfection. This is why we have always had reasons to declare Europe in crisis, to fear it to be under siege, to defend it against an inimical world outside. Europe as the injured innocence, this reading of the myth is apparently obvious. But perhaps it is not the only one.

We could attempt a reading that clings on to the letters, in particular the vowels, of the proper name Europa and identify with her, this young, playful, adolescent girl. Let us follow the vowels as signposts to the actual narrative structure, rather than the spiritual meaning, of the myth. By that token, we acknowledge that the narrative is not about us in virtue of some mediating meaning that we can extract from or impose on it, but in virtue of its reflecting our role in it. Us is what the myth is all about rather than about: de te fabula narratur. We could try to conceive ourselves as Europa before we became Europe. We could imagine ourselves in Europa's place and re-read the myth from this angle as we go through her experiences. We would become aware, gradually rather than retrospectively, to be fascinated, seduced, kidnapped, raped and impregnated by the Greek God and his infinite phallic guises. We would barely remember ourselves as the innocent royal daughter we were at the shores of Phoenicia. Benumbed by the violence we have involved ourselves in, we would hear Aphrodite's voice as from afar. Apparently, she has been in the neighbourhood while all this happened to us. We would wonder why she, of all gods and goddesses, would be in a position to know that once we will give our name to a large continent. Or, for that matter, that a large continent would ever care to carry our name. European identity would be the awareness of innocence lost rather than the triumph of innocence injured. Who inquires about European identity in this way, inquires into the Europe of the vowels rather than the vocation.

The distinction between a Europe of the vocation and a Europe of the vowels was made before, I suspect. It resembles one made by Merleau-Ponty, in his remarkable contributions to the debate on Europe's identity, closely after the Second World War in Geneva. Europe had just found itself back on the ruins of everything that was destroyed, in particular the meaning of words like 'law' and 'human being'. Barely capable of surviving, it posed itself a question, phrased by a number of intellectuals from East and West, from the circles of the vanquished and the victors alike. I quote it from the rather solemn Introduction to one of the editions of these Rencontres internationales ${ }^{27}$ :

\section{'(...) the fundamental question about} the existence of our continent as a spiritual reality (...); is there, indeed, a European spirit and, if so, what it is according to its essence, origin and evolution in the past? What does it mean today? And in which essentially altered reality dwells this spirit and we as its bearers? What is the meaning of this spirit and of the peoples, that reflect its destiny, for the future? ${ }^{28}$ 
Among those who took part in the deliberations were famous persons of the time, like Julien Benda, Denis de Rougemont, George Bernanos, Karl Jaspers, Georg Lukacs, Raymond Aron and others. But if one reads through the proceedings of the conference, it is almost impossible to escape from the conclusion that the most incisive insight into the relative importance of all these ruminations came from the French philosopher Maurice Merleau-Ponty. He argued that the majority of the various contributions systematically set out from Europe as a representation. From this vantage point it is inevitable that the discussion will focus on questions like: what is the content of this representation? is it pre-conceived in the past? should it be realised in the future? and, in particular, how can it be characterised and distinguished from other, allegedly false, representations? Over and against this approach of a Europe 'en représentation', Merleau-Ponty suggests the possibility to reach for unity in a Europe 'en acte', which is to say: in practical ways for men to relate to the world and to each other, particularly in the processes of acquiring knowledge, performing labour and organising a polity. ${ }^{29}$ Those who goes this way ${ }^{30}$ - or so Merleau-Ponty seems to say - will perhaps escape from both Arnheim's and Ulrich's camps. They will not only steer away from Arnheim's cryptofascism, but also from Ulrich's non-commitment. They will perhaps escape from Nietzsche and his diagnosis. For remember that this diagnosis, this critique, aimed at precisely the self-representation of Europe, and at the self-protection and selfpromotion that inevitably come in its tail. Some, Heidegger first and foremost, would even suppose that Nietzsche's own analysis got contaminated by what he criticised, to the point where his own thought got entangled by representationalism in its most radicalist and self-destructive form. ${ }^{31}$ Only, it is not so easy to determine what exactly
Merleau-Ponty meant by his 'Europe en acte'. Certainly, he refers to knowledge, labour, and the organisation of society. What comes to the fore, in other words, are the praxis of science and its concept of truth, the praxis of technology and economics as determinative of labour, the praxis of politics as the enterprise that shapes society into one form or another. But why would these praxeis come to the fore? Why would one not say that what discloses itself in these practices is again this 'typically European' substance, property or vocation, and therefore, again, Europe as representation, as image, as picture of a reality already established in an ideal world? The answer to this question can profit from reading the myth of Europa according to its letters rather than its spirit, from the opposite vowels in the counterparts ereb and $a r a b$. When I now try to explain the direction these practices may go, and go together in an integrated way, all I do in fact is to add some tentative footnotes to a text that was written by Merleau-Ponty.

\section{The vow of the vowels}

One thing is certain: by focussing on 'Europe en acte' we put the question of identity in a practical perspective. Now the perspective of action is a very specific one. Trivial as it may sound, it develops from the agent. Thus, it is the perspective developing from someone who looks ahead, who assesses the situation on the basis of his experience, who scans the causal openings in the intricate network of events as they unfold themselves, who awaits the right time to act as he has decided to do. This perspective is very different from the one developing from a spectator, who looks back upon his acting in retrospect, who assesses its worth with the knowledge that is available in hindsight or according to the goals that are set afterwards. ${ }^{32}$ Of course, the two are interrelated: one who never looks back will never learn from his mistakes and never gather 
experience. But then again, the perspective of action is first and foremost prospective, rather than retrospective. It is the perspective of risk and venture, in which there will never be a warrant that all relevant factors are known, in spite of our will to take the best decision 'everything being considered'. It is the perspective that a priori justifies prudence as its main virtue. Europe 'en acte' reminds us, before everything else, of the gaze in the unknown future ${ }^{33}$ that must have been in the eyes of the Phoenician king's daughter, when she let herself get involved with the Big Greek and was not yet aware of what she was about to find out.

If we turn to the practices - or shall we say the ad-ventures? - of technology and economics, of science and politics, and take Europa's perspective, we have to consider what it would mean to view them within a prospective framework; a framework that commands the kind of prudence that is required if one engages in an enterprise that remains risky in spite of one's experience. Soon enough, we will discover that a specific type of prudence is required in each of the different areas. When it comes to technology, prudence could makes us realise that what can be made does not set the boundaries of what can be thought. When it comes to economics, we may become aware of the fact that a thrifty use of scarce goods on a global scale cannot be commanded, in the final analysis, by offer and demand. The market, as a meeting of offer and demand, can be an effective instrument to distribute scarcity, but it cannot determine the very scarcity it presupposes. When it comes to science, we would not want to ignore our suspicion that all sorts of immunising strategies haunt our received grounds of objectivity. When it comes to politics, we would be prepared to acknowledge that a political enterprise is not possible without presupposing a bounded unity that includes people, but at the same time excludes other people; and that, by definition, it is impossible to justify that very boundary within the political entity created by it. In short, prudence varies with the specific type of venture we engage in as Europeans.

In all of these four different areas it is an open question whether the more or less violent penetration by the Greek logos will be fertilising in the end. Surely Aphrodite made a promise, but whether Europa was pleased to hear it, the story does not tell. It is part of what we dearly want to read as we read in retrospect. If we would be willing to really take Merleau-Ponty's advice, we would perhaps be inclined to be more hesitant. We would wonder if we did not yield to the seduction long ago and, as is usual in such cases, forgot all forms of circumspection. Was it all Aphrodite's work from the start? we would wonder. We would acknowledge that it happened little by little, like the king's daughter began by allowing herself a minor (erotic?) change in her play: she turned, as Ovid tells us, to decorating the bull's, rather than her friends', head with flowers, only to find out, soon enough, that she was not in control of the situation anymore. Can we say that we are? We may have reason to believe that the process of European integration has been a clear example of 'Europe en acte', of prudent and piecemeal engineering towards an uncertain future. But it is far from anything integrated in all of the essentials of social life, and much more similar to a uncontrolled gold-rush towards an old Cretan dream. We could not care less, or so it seems, about the possibly poetic quality of technology, about the ecological metabolism conditioning economics, about the wisdom that might govern science, or about the kind of authority implicitly referred to in the exercise of political power. Thus, it remains an open question whether, in the future, Europe will prove to have given its name to a continent. It might just be that this continent Europe prematurely appropriated the name of the king's daughter. 
Given this predicament, it becomes important to read, once again, the mythology of Europe from its etymology, its vow from its vowels. Let us be as letter-minded as we can. Europa departed from the Phoenician shore, from the borderline that separates $e r e b$ - from arab-land. But the line is a product of thought. It only exists as a function of regions that have segregated themselves with respect to one another. If $e r e b$ and arab are paired references to opposite horizons, it must be the case that the one can only be used if one situates oneself in the domain of the other. Like, from off old, one must be in London to hit Oxford Street and in Oxford to find London Road, so one can only refer to ereb from arab and vice versa. The origin of 'our' identity lies in what is said about us by others.

Thus, a reflection on the role of Europe in the ventures mentioned above should start at what Europe means in the eyes of non-Europeans, at the range of actions or impediments they discover in our ventures, and at the terms that seem apt to them for expressing these conditions and constraints. It is not certain in advance that we are going to like these terms. It is not easy to stay and listen when we are told that we have built a fortress so as to safeguard are own interest first; that we stole our energy supplies without properly paying for them; that we dumped our garbage over the walls of poorer regions rather than cleaning it ourselves; or that we chase patterns of consumption, mobility and productivity that have little to do with what could make humans happy. If there is anything contrary to European self-confidence, it is the awareness that we need a non-European voice in order to discover European identity. Alas, it must be said that, meanwhile, the $a r a b$ regions have closed off their identity in the rebound of European closure. Remember the fatwa that struck Salman Rushdie upon the publication of his Satanic Verses. It has grown to immense proportions now in all sorts of bonds between religious fundamentalism, oppression and terror. And it seems to be drifting westbound.

There is a last facet that needs to receive some light in this footnote to Merleau-Ponty's phrase about 'Europe en acte'. It has to do with a tantalising statement by Mikhail Gorbachev in his Oslo 1991 speech, when he received the Nobel Prize for Peace. ${ }^{34} \mathrm{He}$ saw 'the European space' as 'going beyond its nominal geographical boundaries', reaching from Los Angeles over Europe to Vladiwostok. He did not promote this as a new enclosure of the northern hemisphere to shield off a sort of 'global Europe' from the rest of the world. But he wanted to join his Italian colleague Andreotti in his view that 'East-West rapprochement alone is not enough for progress of the entire world towards peace. However, agreement between them is a great contribution to the common cause'; and that it entails openness towards other countries and regions. Indeed, in a considerable number of contexts erep and arab have begun to refer to north and south rather than west and east. These vowels are variables rather than values. It should, perhaps, be taken as a prophecy that the original axis of their referential structure was in fact in-between these directions: erepland in the north-west rather than the west, arab-land in the south-east rather than the east. But I concede: this is far too good to be true on top of all the surmises we have already permitted ourselves. And yet, this toppling over is a new exhortation to take the myth of Europa literally: indeed, Europe will give its name to a continent, only it does not know in advance which continent. People from Arabian and African countries risk their lives on wrecked boats to reread these vowels. Europe is the continent which is not in a position to know yet how erep and arab will topple over in the future. Thus, it is not in a position to know yet 
what will appear to be its opposite horizons; Russia? Syria and Irak? Saudi-Arabia? Greece itself as it falling out of the Euro-zone? ${ }^{35}$ Which mirrors it will have to face in order to assess its own situation and identity, is impossible to know beforehand. ${ }^{36}$

We undertook a re-reading of the myth of Europa, at least part of it and in its simplest form. We refrained from exploring all the symbolic forces that seemed to radiate from it. We did not, for instance, study the fact that Minos, one of the two sons borne out of the intercourse between Europe and the Great Greek, entered into a marriage that generated the man-devouring Minotaurus. We have ignored the question how Aphrodite acquired her knowledge about the future. Was it something only women can know? Did she sense that her son, Aeneas the Trojan, would come to dwell in Latin surroundings? These and many other questions were put aside. Instead, we tried not only to re-read, but to read in a different way: to trace the vow of the myth from its vowels rather than its vocation. We tried to detect its meaning by imagining ourselves to be Europa, rather than Europa to be us. Nietzsche convinced us that this could be the only way to shield ourselves from yet another exercise in European self-indulgence. Merleau-Ponty pointed to an alternative that has to be explored in much more detail, but which, at least, had the merit of turning our faces into the direction in which the story points: a gaze into the future. Identity, not as a stubborn repetition of the same, but as a prudent unfolding of oneself - it is a venture that will cost Europe dearly, in terms of time, money and courage.

My thanks for guiding me on these journeys go to fellow-travelers Anton van Kalmthout, Frans Pennings, Sanne Taekema, Luigi Corrias, and, above all, Heidrun Peters.

2 An earlier version of this paper was discussed in the panel 'Europe and the Cosmopolitan Citizen', at the conference 'Towards a European Society? Transgressing Disciplinary Boundaries in European Studies Research', organized 28-30 June 2012 by the Centre for European and International Studies Research in Portsmouth (UK). I thanks the participants in the panel for their comments. Parts of the paper appeared also in Dutch in a booklet Europa, de geest en de letters (1998).

3 For references, cf. Rujivacharakul, V., H. Hazal Hahn, et al., Eds. Architecturalized Asia: Mapping a Continent through History. Hong Kong, Hong Kong University Press, 2013, 86.

4 The clue to which I derive from J.-P. Faye, L'Europe une. les philosophes et l'Europe. Paris, Gallimard, 1992, p. 19. See, for instance, G. Soulier, L'Europe. Histoire, civilisation, institutions. Paris, Armand Colin, 1994, p. 13vv.

6 '(...) das Meer mit seiner beweglichen Schlangenhaut und Raubthier-Schönheit (...)'. Nietzsche, Menschliches, Allzumenschliches, II, 1, 49. The sea itself, rather than the bull, is the beast of prey. In this passage by Nietzsche, it is the symbol of the loss of innocence with regard to the world.

7 'Warum doch gerade in dieser Richtung, dorthin, wo bisher alle Sonnen der Menschheit untergegangen sind?' Nietzsche, Morgenröthe, V, 575.

8 In the present circumstances of official politics, Turkey, of course, is not an 'Arab' country. But it is considered to be 'arab' or 'oriental' in less official surroundings. In Latin-American countries everyone with a Arabian or Turkish background is called 'turco', even if he is a president. And the average Dutchman perceives Turks and Marroccans as 'the same' to such an extent that their shopkeepers started to sell each other's products in return of the permanent confusion.

9 A strong case in point, that an innocent tourist will not discover even if he is on the very spot, are the ruins of Ba'ram in Galilea.

10 It is not only remarkable how the state of Israel represses the Arab population with totalitarian means (among these: approval of torture as "mild physical pressure" by the High Court), but also how the schematisms of the Shoah are reactivated within the Israelian state itself: settlers who refer to themselves as the 'jews', that is to say the outcasts, of the state of Israel (see the reader's page of the Jerusalem Post of 25 August 1992), or fundamentalists (as well as political profiteers of fundamentalism) that referred to Rabin as a nazi.

11 Menschliches, Allzumenschliches, I, 265.

12 Íntroduction. In: En quête d'Europe. Rennes, Éd. Apogée, 1994, p. 11.

13 Judgment 30 Juin 2009, 2 BvE 2/08, para 251. For the earlier BVerfG decision on the Maastricht Treaty of 12-10-1993, see Eur. Gr. Z. 1993, p. 429vv..

14 K.A. Schachtschneider, Res publica res populi. Grundlegung einer Allgemeinen Republiklehre. Ein Beitrag zur Freiheits-, Rechts- und Staatslehre. Berlin, Duncker \& Humblot, 1994, p. 1191. Critical towards both the decision and Kirchhof's approach: J. Weiler, 'The Transformation of Europa.' In: The Yale Law Journal, 100, 1991, $2403-2483$.

15 F. Fukuyama, The End of History and the Last Man. New York, Avon Books, 1993.

16 I am aware of the bravado at the beginning of this sentence: as if I had read Nietzsche and could teach Fukuyama a lesson. 
It is no doubt far closer to the truth when I admit that I hardly have any idea of what it means 'to have read Nietzsche'. In any case I am indebted to my colleague and far more experienced reader, the late Bas van der Kleij, for references to some passages that would otherwise have escaped my attention.

${ }_{17}$ Nachlass achtziger Jahre, p. 660. Cf. 11 [235] [11 = W II 3] Faye, p. 237. Colli - Montinari, Nietzsche Werke, Bd. VIII, 2, p. 335.

18 'Der Europäer verkleidet sich in die Moral, weil er ein krankes, kränkliches, krüppelhaftes Tier geworden ist, dat gute Gründe hat, 'zahm' zu sein, weil er beinahe eine Missgeburt, etwas Halbes, Schwaches, Linkisches ist (...). (...) Moral putzt den Europäer auf - gestehen wir es ein! - ins Vornehmere, Bedeutendere, Ansehnlichere, ins 'Göttliche' - Zie Par. 352; cf. Jenseits von Gut und Böse, 62: '(...) Gesetzt, dass man mit dem spöttischen und unbetheiligten Auge eines epikurischen Gottes die wunderlich schmerzliche und ebenso grobe wie feine Komödie des europäischen Christenthums zu überschauen vermöchte, ich glaube, man fände kein Ende mehr zu staunen und zu lachen; scheint es denn nicht, dass Ein Wille über Europa durch achtzehn Jahrhunderte geherrscht hat, aus dem Menschen eine sublime Missgeburt zu machen? (...) solche Menschen haben, mit ihrem 'Gleich vor Gott' bisher über dem Schicksale Europa's gewaltet, bis endlich eine verkleinerte, fast lächerliche Art, ein Heerdenthier, etwas Gutwilliges, Kränkliches und Mittelmässiges, herangezüchtet ist, der heitige Europäer.' Cf. ibid., 199.

19 'Denn so steht es: die Verkleinerung und Ausgleichung des europäischen Menschen birgt unsre grösste Gefahr, denn dieser Anblick macht müde .... (...) Hier eben liegt das Verhängnis Europas - mit der Furcht vor dem Menschen haben wir auch die Liebe zu ihm, die Ehrfurcht vor ihm, die Hoffnung auf ihm, ja den Willen zu ihm eingebüsst. Der Anblick des Menschen macht nunmehr müde - was ist heute Nihilismus, wenn er nicht das ist? ... Wir sind des Menschen müde ... Zur Genealogie der Moral, 12.

20 'Ein Dichter könnte sagen, dass Gott die Vergesslichkeit als Thürhüterin an die Tempelschwelle der Menschenwürde hingelagert habe.' Menschliches, Allzumenschliches, I, 92.

${ }^{21}$ Jenseits von Gut und Böse, 201. Cf. 202: ‘(...) eins im zähen Widerstande gegen jeden Sonder-Anspruch, jedes SonderRecht und Vorrecht (das heisst im letzten Grunde gegen jedes Recht: denn dann, wenn alle gleich sind, braucht niemand mehr 'Rechte'-);(...).'

22 'Wir fanden, dass in allen moralischen Haupturtheilen Europa einmüthig geworden ist, die Länder noch hinzugerechnet, wo Europa's Einfluss herrscht: man weiss ersichtlich in Europa, was Socrates nicht zu wissen meinte, und was jene alte berühmte Schlange einst zu lehren verhiess, - man 'weiss' heute, was Gut und Böse ist.' Jenseits von Gut und Böse, 202.

23 Numbers between brackets in this section refer to the pages in the Dutch translation of the novel.

24 Ph. Payne, Robert Musil's The Man without Qualities. A Critical Study. Cambridge etc., Cambridge University Press, 1988, p. 176.

25 Cf. H.-G. Pott, Robert Musil. München, Fink Verlag, 1984, p. 104.

26 Payne, ibid., p. 71.

27 L'Esprit européen, in Rencontres internationales de Genève, 1946. Neuchatel, Les Editions de la Baconnière, 1947. Contributions by Merleau-Ponty can be found at pp. 74-77; 133; 252-256.

28 Ibid., 7. If one would translate the out-dated idiom of the formulations, it would appear that both the form and the content of this conference is not very different from the one we see reported at the threshold of the 21st century (1995) in the volume En quête d'Europe under the direction of Jacques Delors (Les carrefours de la science et de la culture). The only difference in idiom is probably this, that what, at that time, was called 'the European spirit' is now preferably called 'the European identity'. But then, the old phrase is still in use, and the new one was at the time.

29 For more interventions in the debate by Merleau-Ponty, see La connaissance de l'homme au XXe siècle, Rencontres internationales de Genève, 1951. Neuchatel, Les Editions de la Baconnière, 1952, pp. 51-75; 182-183, 186 and scattered commentaries, pp. 210-296.

30 An incisive philosophical exploration of this road is offered by Hans Lindahl, Welfare and Enlightenment. An Enquiry into the Rational Foundations of the Welfare State, Leuven, Leuven University Press, 1995.

31 This is, of course, a very brief summary of Heidegger's argument. Cf. Nietzsches Lehre vom Willen zur Macht als Erkenntnis, in Gesamtausgabe, II Abt., Bd. 47. Frankfurt a.M., V. Klostermann, 1989 (1961) [1939].

32 'Der europäische Mischmensch - ein leidlich hässlicher Plebejer, Alles im Allem - braucht schlechterdings ein Kostüm: er hat die Historie nöthig als die Vorrathskammer der Kostüme. Freilich bemerkt er dabei dass ihm keines recht auf den Leib passt, - er wechselt und wechselt.' Nietzsche, Jenseits von Gut und Böse, VII, 223.

33 '(...) wo Alles noch Meer, Meer, Meer ist!' Nietzsche, Morgenröthe, 575.

34 See http://www.nobelprize.org/nobel_prizes/peace/laureates/1990/gorbachev-lecture_en.htm, accessed $4^{\text {th }}$ Juin 2015.

35 '- Und wohin wollen wir denn? Wollen wir denn über das Meer? (...) Wird man vielleicht uns einstmals nachsagen, dass auch wir, nach Westen steuernd, ein Indien zu erreichen hofften, - dass aber unser Loos war, an der Unendlichkeit zu scheitern? Oder, meine Brüder? Oder? - ' Nietzsche, Morgenröthe, 575.

36 '(...) vielleicht gab es noch niemals ein so «offnes Meer». -' Nietzsche, Die fröhliche Wissenschaft, V, 343. 


\title{
Курс на Восток - курс на Запад: \\ перечитывая миф о Европе
}

\author{
Берт ван Роермунд \\ Университет Тилбурга \\ Нидерландь
}

\begin{abstract}
Идентичность Европы не просто оспаривается, оспариваются ее отдельнье составляюшие. Какие именно характеристики (ценности наследие, или род занятий) однозначно идентифиичруют Европу? По всей видимости, любая позиция, занятая в данной дискуссии, приведет к значительным последствиям, например, в отношении внешней политики (следует ли Евросоюзу включить Туричю в свой состав?) или внутренней институцчонализачии (существует ли европейский народ?). Все эти доводы, без исключения, вытекают из представлений о прошлом Европь. В настоящей статье оспариваются общепринятые утверждения, исходя из различий между 'Europe en représentation' $u$ 'Europe en acte', на которые указывал Мерло-Понти. Прежде всего, исследуется, как повествование о прошлом Европь растворяется в мифе, который мы не можем воспроизвести, но от которого не в силах избавиться. Во-вторых, рассматривается резкая критика репрезентационного взгляда на Европу, которую нам приводит Ницие. Здесь автор впервые обращается к точным, но достаточно противоречивым заметкам Ницие; далее анализируется, как те же самые темы отражень в одном из величайших, по мнению автора, романов о Европе ХХ века, "Человек без свойств» Роберта Музиля). В-третьих, в статье утверждается, что альтернативное понимание идентичности в рамках 'Europe en acte' позволяет развернуть миф о Европе в перспективе, а не в ретроспективе, принимая во внимание сиенарии, по которым различные страны в рамках Евросоюза потеряли свою идентичность, чтобы объединиться для благоразумного решения трех основных задач будущего: развития технологий, экономики и верховенства закона. Следовательно, дискуссия об идентичности должна больше опираться на коллективную индивидуальность, чем коллективное единообразие.
\end{abstract}

Ключевые слова: европейская идентичность, индивидуальность и единообразие, взаимоотношения Востока и Запада, политические границь, Ницчие.

Данная статья посвящена юбилею Юридического института.

Научная специальность: 12.00.00-юридические науки. 